\author{
群馬大学医学部, 解剖学敎室 (主任 : 伊東教授)。 \\ Anat. Inst., Gunma Univ. Maebashi (Vorstand: Prof. T. ITO).
}

\title{
高年者の再证腺の細胞学的研究.
}

\section{Cytologische Untersuchungen über die Gl. ceruminosa bei gealterten Greisen.}

\author{
永川俊彦, 飯島剛, 田中愛雄 \\ Toshihiko NAGAKAWA, Takeshi IJIMA und Yoshio TANAKA.
}

(Eingegangen am 26, Oktober 1957.)

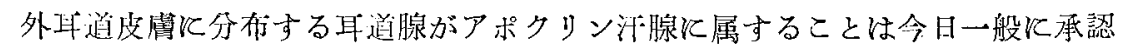
されるところである，古来この腺に関して論ぜられたのは脂肪を分泌するか否か の問題であるが (牦曽越 1951 参照), 最近 Montagna, Noback そ Zak (1948) は人 の耳道腺の組織化学的研究飞於て, 腺細胞の中飞色素顆䊑, 脂肪顆粒等を証明し, その色素分泌及び脂肪分泌を確認すると督に，耳道腺細胞が脂肪滴で充満して皮 脂腺細胞類似の形態をとることがある点に注目した。次いで猫の外耳道腺に於て も維織化学的研究を行い，近似する成績を得た (Montagna 1949)。臂曾越 (1951) も人の耳道腺細胞内飞色素及び脂肪の存在を証明し, 乙等が分泌顆䊀に含まれて 出現することを確かめた，この研究によって彷来別個の顆粒として観察された色 素顆粒，脂肪顆粘及び分泌顆粒は同一の構造物であることが証明された。尾曽越 も Montagna 等と同様，耳道腺細胞が脂肪滴で充たされて皮脂腺細胞の如き姿を 呈することがあると報告し，耳道腺では分泌顆籹の脂肪化が㤝く，高度の脂肪分 泌を行い，汁腺の中で最も皮脂腺飞近似した腺であるとの見解を述べた，之等の 研究によって耳道腺の脂肪分泌の問題は解決されたと見るべきである。他方伊東 と協力者による高年者の汗腺飞関する 2,3 の報告がある（岩重 1951，1952，特野 1951，伊東と岩重 1953)。特野 (1951) と岩重 (1952) とは高年者の全身諸部及び 腋简のエックリン汗腺を観察し，老人性変化として腺細胞の萎縮，分泌機能の低 下, 腺細胞の脂肪化とリポフスチン顆粒の出現, 腺細胞の Golgi 装置の脂肪化, 筋上皮細胞 (平滑筋細胞) の萎縮或は堙大, 脂肪化, リポフスチン顆䊉の出現, 往 ってとの收縮機能の低下等を挙げた. 又伊東と岩重 (1953) は高年者の腑窝ア-汁 腺を観察し，腺管と腺細胞の萎縮は 60 才以後に著明となり，腋臭者に於て高度で あり，又腺細胞の分泌機能の低下，組胞質の空胞化とエー汗腺程高度ではないが， 脂肪化があり，更飞筋上皮細胞の萎縮，空胞化，腈大，脂肪化，リポフスチンの出 現等があると報告した。 之等の研究は人の汁腺の老人性变化を細胞学的に辣細に 観察した最初のものである. 
ア-汗腺の一種である耳道腺が高年者に於いて如何なる変化を示すかが本研究 の主題であるが，この問題については今日までに 2,3 の簡単な報告がある，田所 （1909）は耳道腺は老年江到って腺腔は抬大し腺細胞は漸次扁平となると述べ，長 島 (1934) 恃老人に於ても十分飞機能を営むことを示す像を認め, 広田 (1939) は 極めて高年になって初めて变化が現われるが，老人性萎縮はないと思われると報 告した，屒島と広田の論文を見ると耳道腺には老人性変化は容易に現われない ようであるが，更に竬細な細胞学的観察が必要である。吾々は最近の琵曾越 （1951）の詳細な細胞学的成績に照らして高年者の耳道腺を観察した. 人の汗腺は

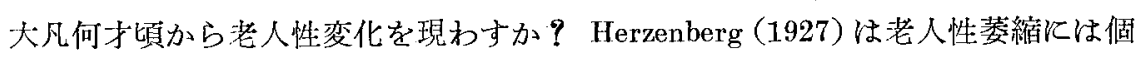
人差があると言い，長島 (1934) は40才前後に荌縮が括こると述べ，菅 (1941)は 45 才前後より機能娍退が括こると述べた。 又 Ito（1943）は41才女子の脑简エー汗 腺の腺細胞の脂肪化が既に強いのを注目している。吾々の材料は50才ー89才の人 から採取した外耳道皮膚である。

成田 (1954)の研究飞よれば, 人胎尘耳道腺の腺細胞に分泌顆料の出現するのは 胎坐 6 ケ月でアポクリン分泌像を現わすのは 7 ケである。牧窝アー汗腺に於て分 泌顆精の出現は营 (1941) 飞よれば胎生8 ケ月であり，永川（1957）によれば胎生 9 ケである。分泌顆䊀の出現を以って分泌機能開始と莙えるならば，耳道腺は

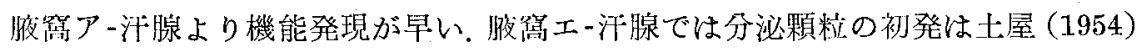
飞よれば胎生7ケ月であるから，てれよりる早い，併し成田によれば胎生期の分 泌顆粒は脂肪と色素を含まない.小山（1925）〕胎生期には脂肪は証明されず, 生 後 1 ケより 70 才にいたる間には脂肪が証明されると述べ, 長島 (1934) も亦脂 枷は1ケ月の乳傴から初めて証明されると述べている，従って耳道腺の脂肪分泌 ほ生後に始まる，以上の如き今日までの文献て述べられた成績を総括して見ると 耳道腺浪も早く分泌機能を開始し，老年期に到るる老人性変化を現わすことの 最も少ない汗腺ではないかと想像される。

\section{I. 研究材料と方法。}

研究材料は特野 (1951) が全身8体部のエ-汗腺を研究した 89 才。，83才字（以 上老衰死)，63才今 (脳軟化症)，50才合(栄養失調飞よる衰弱死)の4屍から採取 した外耳道軟骨部の皮䖉で, 死後 6 時間以内 (冬期) 飞採取し直ちに固定した. 63 才の例任死後 1 時間に大腿動脈か $510 \%$ Formalin を注入して全身を固定し, 翌日 外耳道皮虞を採取して他の例々问様次の如き固定液に投大し再固定した。使用し た固定液はLevi 氏オスミューム酸混合液, Zenker-Formol (固定 24 時間後 $3 \%$ 重 クローム酸加里液に 5 日間投入す), Formol-Alkohol で, 染色は Heidenhain 氏鉄 ヘマトキシリン, ヘマトキシリン(Hansen 氏)ーエオシン重染色を用い,グリコゲン 染色飞はPAS 法（過沃度酸 Schiff 反応）を用いた。系粒体はLevi 氏液固定或は Zenker-Formol 固定，鉄へマトキンリン染色標本でよく検出された。脂肪は Levi 
氏液固定標本で褐色乃至黒褐色飞着色して保存される.色素顆粘はZ Zenker-Formol 固定, ヘマトキンリンーエオジン染色で最もよく観察される。固定した外耳道皮算 はアルコールで脱水し, キシロールを経てパラフィンに包理し, 4-5 厚の連続 切片とした。

\section{II. 所見と考察.}

\section{A. 一般的所見.}

外耳道皮厴には著明な萎縮は見られなかった, 表皮の厚さ, 真皮乳頭の状態に る著明な変化はない，皮下脂肪組織は全例に於て少ないが，脂肪細胞に変化はな い. 特野 (1952) は本研究と同じ屍体から採取した腋窝, 頭部, 煩部, 胸部, 腹部,

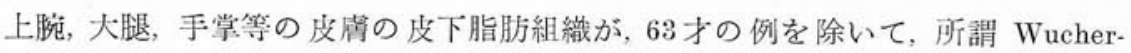
atrophieに陥っているのを見たが, 老人性変化ではなく, 大戦直後の生活環境悪化 飞伴う栄養然調によるものと断定し, 手掌に於ては全例に於て, かかる変化は全 く認められない点に注目したが, 本研究によって外耳道皮原にも Wucheratrophie は全例に認められないことが明らかとなった。

耳道腺は他のア-汗腺がそうであるように毯状腺 (Knäueldrüse) であって, 長い 上皮管は腺管 (分泌部) と排泄管とに分たれる.腺管は上皮管の大部を占めて長く 迂曲して糸逑, 即ち腺体を作るが, 尾曾越 (1951) も認めているように排泄管は エ-汗腺とは異り, 糸球の形成に与らないで (伊東 1949 参照), 腺体から離れて真 皮内を上行し, 一般に短い経過の後に毛包の上部に開口する. 吾々の標本は細胞 学的観察を主目的として作られたので, 排泄管の長さ, 迂曲, 開口部等の観察には 適していないので, か かる問題に対して確実 な解答は得られなかっ たが, 吾々の観察した 範同では一般に排泄管 は短かく, 迂曲子著明 ではなく, 毛包の上部 へ開口するものしか見 当らなかった（図1）. Alzheimer (1888), 田 所 (1909), Stöhr 等飞 よると，成人では耳道 腺の排泄管は生毛に接 して表皮の表面に開口 するという. Montogna, Noback と Zak (1948)

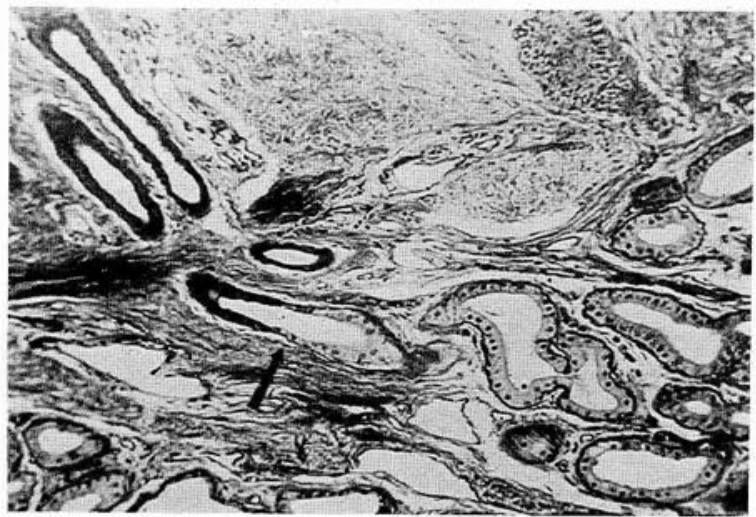

汹1. 耳道腺の腺体と 2 本の排泇管（暗調, 左上）及び腺管と 排沺管の移行 ( $\uparrow$ ). 50 才男. Zenker-Formol 固定, 鉄へマト キンリン (Heidenhain) 染色. $120 \times$.

Abb. 1. Drüsenkörper und zwei Ausführungsgänge (dunkel, links oben) sowie Übergang des Drüsentubuls in Ausführungsgang $(\uparrow)$. 50jähr. Mann. ZENKER-Formol, Eisenhämatoxylin (HEIDENHAIN). 120×. 
は生後14ケ月から64才までの人の耳道腺で長い排泄管は普通直接表皮表面に開口 し，時に皮脂腺の排泄管へ開口するのを認めた。吾々はかかる所見に遭遇しなか った。 併し Eckert-Möbius (1926), 尾曾越 (1951)によると成人に於ても1部の腺 は毛包の上部へ開口するという。.Montagna 等(1948) によると耳道腺の排泄管は 特に老人に於て一般に搪大し, 開口部に近く卵円形の囊を形成するという。吾々 も50才例飞於いて，かかる拨大部を持つ腺に遭遇したが(図1)，89才例に於ては 搥大は見られなかった。. 排泄管上皮は内層及び外層細胞の 2 層から成り, 内層細胞 は立方形で表面に教皮層を持つ。拡大部では上皮細胞は扁平となる.成田 (1954) は胎生期には腺管と排泄管との間に移行部（伊東と円乗 1949）があると述べたが, 吾々は確実に見分けることが出来なかった.

腺管が形成する系毯, 即ち腺体は真皮から皮下組織に互って存在する. 腺体の 大きさ, 腺管の太さ管は個々の腺によって異るが, 一般に89才例に於ても萎縮が あるとは思われない，併し50才例では大きい腺が最も多く見られ，89才例では腺 は一般に小さい. 又腺細胞の高さ, 大きさ等から見ても老人性萎縮の徴候は認め られない，腺管の太さはアー汗腺の特徵として同じ腺に於ても部位によって異る が，一般に腺腔はエ-汗腺より広い。特に 63 才と 83 才の 2 例に於て腺腔が非常に 挀大し，腺管も非常に太い腺が多く認められた。拡大した腺腔にはコロイド状或 は雲絮状の内容が潜溜するのが見られた。 伊東と岩重 (1953)は老人の腋㸗ア-汗 腺で，腺膛にコロイド状内容が热溜することが多くなるのを見ている，かかる部

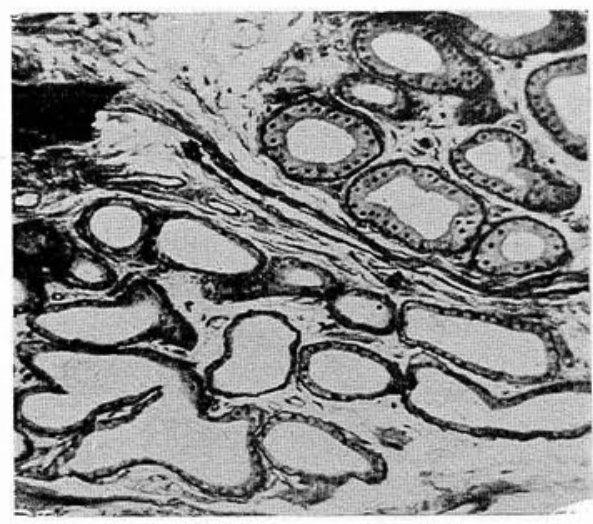

困 2. 䕛い腺涳と高い腺上皮を持つ耳道腺と広 い腺腔と低い腺上皮を持つ耳道腺の腺体。 50 才 男. Zenker-Formol 固定, 鉄へマトキシリン (Heidenhain) 染色. $120 \times$.

Abb. 2. Drüsenkörper der Ohrenschmalzdrüse mit engerer Drüsenlichtung und höherem Drüsenepithel und der mit weiterer Drüsenlichtung und niederem Drüsenepithel. 50 jähr. Mann. ZENKER-Formol, Eisenhämatoxylin (HEIDENHAIN). $120 \times$.
分に於ては腺細胞は扁平である。併 し 50 才と 89 才の 2 例ではかかる腺 は少ない，腺腔の㹨い腺或は腺管の 部分では一般に腺細胞は高く, 円 柱乃至立方形である(図 2 ). 田所 （1909）は老年飞到って腺整が拡大 し，腺細胞は㰾次扁平となると述へ たが，吾々はかかる説を支持する如 き所見を得ていない.

糸趐即ち腺体の形は種々であるが, 一般に軟骨と表皮との間の皮留結合 組織が広い部分では系政はまとまっ た腺管の集団を形成するが，狭い部 分では軟骨表面に沿って長く螺旋状 に延びることが屡々ある。 かかる状 態も亦恐らく老人性現象ではない. 89才の例に於て吾々は系㲑を作らな いで殆んど真直に走る短い腺管から 
出来た耳道腺に遭遇した. か かる糸毬を作らない単管状の 腺は軟量と表皮の間が非常に 狭い部分に見られた（図3）. 腺釉は狭く，腺細腺は高円柱 形でアー分泌像を示している. 即ち腺細胞飞萎縮はなく, そ の機能も低下していない. か かる短い腺が老人性萎䋩によ り，腺管が短縮して出来たも のと考えることは困難であっ て, 恐らく若い人にも見られ るのではないかと想像される.

高年省に於て耳道腺の量の 減少はないかという問題を考 えて観察したが, 各例に於て

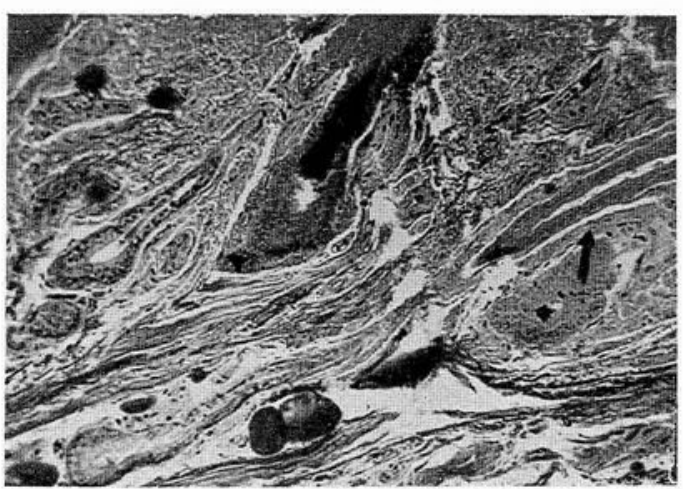

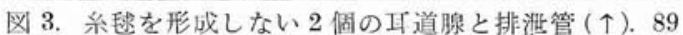
才男. Levi 氏液固定, 鉄へマトキンリン (Heidenhain) 染色. $120 \times$.

Abb. 3. Zwei kein Knäuel bildende Ohrenschmalzdrüsen und Ausführungsgang $(\uparrow)$. 89 jähr. Mann. LEVIsches Gemisch, Eisenhämatoxylin (HEIDENHAIN). $120 \times$. 共に耳道腺の量は部位によって異るので，吾々の作ったような小切片ではこの問 題を解決することは困難である.

腺管壁の構造は尾曾越 (1951) の報告の道りであって, 腺膑を囲んで腺細胞が 1層に規則正しく配列し, 遊離表面間には閉鎖堤があり, 細胞間分泌細管は存在 しない，その外側には筋上皮細胞が一層に並ぶ，腺管の長軸と一致する方向に延 びるので，腺管の横断面で見ると大なる腺細胞の基底部へ凸出する丘形，半月形 の小細胞として認められる. エ-汗腺のものと比較して特に発達がよいと思われ ない. 筋上皮細胞の外囲は固有膜で包まれる.

腺細胞の 細胞質は他のア-汗腺の如く一般に鉄へマトキンリン，へマトキンリ ンーエオシンで良く染まり暗調である。核は円形或は梅円形のことが多く,大なる 核小体を 1 個或は中等大の るのを $2-3$ 個持つことが多い. 核の位置は一般に細 胞の中央より基底側にやや偏することが多く，核の数は普通1個であるが，稀れ に 2 核の細胞が見られた (尾曾越 1951 参照). 全例に於て核内に極めて薄い染色 質膜で包まれた空膛が貫々認められた。 その大きさと数は種々で, 大なるすのを1 個持つものもあり (図 4), 小なるるのを数個持つるのるある. その起源は不明で あって，核小体に由来する核小体胞 (Nucleolarblase) であることを示す所見は見 られない. 最も考えられることは脂肪細胞の核に見られると同様な脂肪滴の溶解 によって形成された空胞ではないかという想像である（伊東, 成田, 大屋, 永川 1956 参照). 後に述べるようと耳道腺細胞は脂肪形成の旺盛な細胞であって, て の点飞於て脂肪細胞と類似している. かかる核内の空胞が老人の耳道腺にのみ出 現するか若い人にも出現するかは不明であるが, Montagna, NobackとZak (1948), 
尾曽越 (1951) の研究には記載されていない.

筋上皮細胞 (平滑筋細胞) 飞は老人性変化と思われる強い変化が見られるので 項を改めて後述する.

\section{B. 腺細胞の細胞学的所見.}

高年者の耳道腺に何等かの老人性変化があるならば，それは腺細胞にも現われ る筈である.上述の如く腺細胞には老人性菱縮は認められないが, 尚お予想され ることは腺細胞の分泌機能の低下に伴って現われる分泌像の変化である. 吾々は 尾兽越 (1951) の 1 例の 56 才男子を含む27-35才男子から採取した 6 例の外耳道 皮扸に於ける耳道腺の詳細な細胞学的所見を参照して観察を進めた.

a) 腺細胞遊離表面の構造.

伊東 (1949) が総括的に述べた如く, 一般にア-汗腺細胞の遊離表面即ち腺䐋面 には沜皮層 (Crusta) と呼ぶべき緻密な暗調均質性原形質層がある. これを小皮縁 (Cuticularsaum) と呼ぶ学者もある.耳道腺細胞に於てもその存在が認められてい る (尾曽越 1951 参照). 高年者の例に於ても常にその存在が認められた (図 4-9). 喑調緻密で均質性の層であって, 糸精体, 分泌顆粒等も殆んど存在しない. この 没皮層の厚さは細胞によって異るが，機能時期によって殆んど消失する場合があ る (後述). Minamitani (1941b) と大田 (1950b) は人の腋窝ア-汗腺の腺細胞の改 皮層の表面に刷子緣椂の構造を認めたが，総ての細胞に常に見られないと述べた。 併し尾曾越 (1951) は人の耳道腺細胞では全く認めないと報告した. 最近伊東, 高 橋と北川 (1956) は人の腋召ア-汗腺とエ-汗腺に於て過沃度酸-Sehiff 反応 (PAS) によって染色した標本では腺細胞のみならず，排泄管上皮細胞にも常に刷子縁が 証明され，特にアー汗腺細胞では厚くて容易に認められると報告した.

吾々は高年者の耳道腺細胞の娎皮層表面に全例飞於て可なり厚く, 腋窝ア-汗

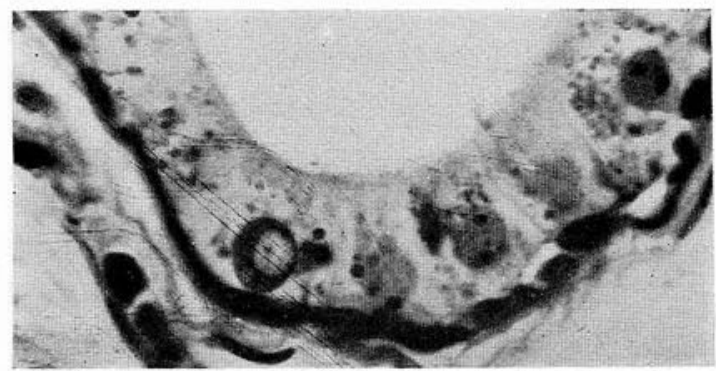

区 4. 1 個の大なる空胞を持つ腺細胞の核。腺細胞は種々 の大きさの分泌顆粒を持つ. 卭道腺, 50 才男. ZenkerFormol 固定, 鉄へマトキシリン (Heidenhain) 染色. $1100 \times$.

Abb. 4. Eine große Vakuole führender Kern der Drüsenzelle. Drüsenzellen enthalten verschiedengroße Sekretgranula. 50jähr. Mann. ZENKER-Formol, Eisenhämatoxylin (HEIDENHAIN). $1100 \times$.
腺の腺細胞飞匹敵する刷子 縁を大多数の細胞に於て証 明することが出来た（戝 4, 7). PAS 反応, 鉄へマトキ ンリン及びへマトキシリ ンーエオシン染色によって 良く染色証明され，遊離表 面から垂直飞派生する微細 な小桿が密に並例するとと によって形成される. 刷子 縁は電子顕微鏡で数多くの 上皮細胞の遊離表面飞認め られる微細な原形質突起即 
ち microvilli である (伊東, 高橋, 北川 1956 参照). Microvilli は殆えど総ての上 皮細胞にあると想像されるが，光学顕微鏡で見えるか否かは，その長さ，太さ及 び密度等の差による。耳道腺細胞に存在するとして子不思議ではないが，その機 能的意義は不明である.

b) 糸粒体 (Mitochondria) と分泌顆粒の形成.

人の耳道腺細胞の系粒体に関する報告は非常に少ない. 最近 Montagna, Noback と Zak (1948) は Baker の acid haematein 法 (燐脂質検出法) を用いて耳道腺細胞 の中に球形顆粒及び小桿を証明し，その細胞内分布状態は Nicolas, Regaudと Favre （1912）が述べた汗腺細胞の糸粒体のそれと類似すると報告した，尾曽越 (1951) は初めて人の耳道腺細胞の糸䊀体を詳しく記載した。 それによると糸精体は緩く 彎曲する糸状及び桿状で少数の顆籹状のものを混じ，分泌顆粒を持たない腺細胞 では遊離表面にある暗調均質性層 (梊皮層) を除いて原形質全域に略々平等に分 布するが，分泌顆粒を持たない細胞は稀れで，その增加に伴って糸粒体は少なく なるという．吾々は高年者の耳道腺細胞に於て尾曾越の報告と一致する所見を得 た. 高年者に於ても分泌顆粒を持たない腺細胞は稀れであるが，糸粒体は糸状， 桿状で少数の顆粒状のものを混じ，敖皮層を除いて原形質の全域に略々平等に分 布し, 円柱形乃至立方形に近い細胞では細胞長軸と平行するすのが多く, Minami$\operatorname{tani}(1941$ b) が腋窩ア-汗腺で見た如く, Golgi 野に欠如するととはない（図 5 ). 糸粒体の量は50才例飞於ても 89 才例に於ても余り変りはなく, 尾曾越 (1951) の壮年者のもの の図と比較して決して減少して いるとは思われない，伊東と岩 重 (1953) は高年者の腋召ア-汗 腺に於て腺細胞の糸粒体の減少 を認めたが，耳道腺に於ては腺 細胞の荌縮も顕著でなく, 又糸 粒体の減少もない，併し尾曾越 （1951）が認めたよ うと，高年者 飞於て子腺細胞の糸粓体は分泌 顆粒の量に反比例して減少する. 即ち分泌顆精を多く持つ細胞で は糸精体は少ない，この事実は

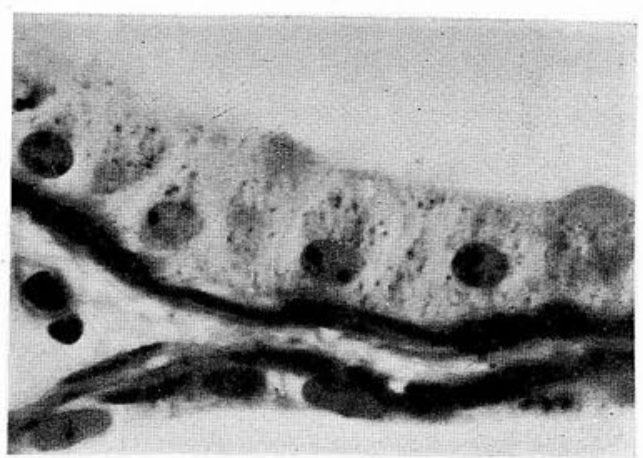

図 5. 円柱形腺細胞の系粒体. 耳道腺, 50 才男. Zenker-Formol 固定, 鉄へマトキシリン (Heidenhain) 染色. $1100 \times$.

Abb. 5. Mitochondrien der zylindrischen Drüsenzellen. Ohrenschmalzdrüse, 50 jähr. Mann. ZENKER-Formol, Eisenhämatoxylin (HEIDENHAIN). $1100 \times$.

糸粒体から分泌顆粒が形成されることを暗示する. 又との事を証明する如き糸粒 体と分泌顆粒の変化が認められる. 即ち糸状或は桿状の糸粒体の末端とある肥孛 部が漸次增大し，棍棒状や亜鈴状となり，それが離断されて分泌顆粒となる像が 数多く認められる (図 6,7 ). 從って分泌顆䊀が 2 個ずつ対をなして存在すること 


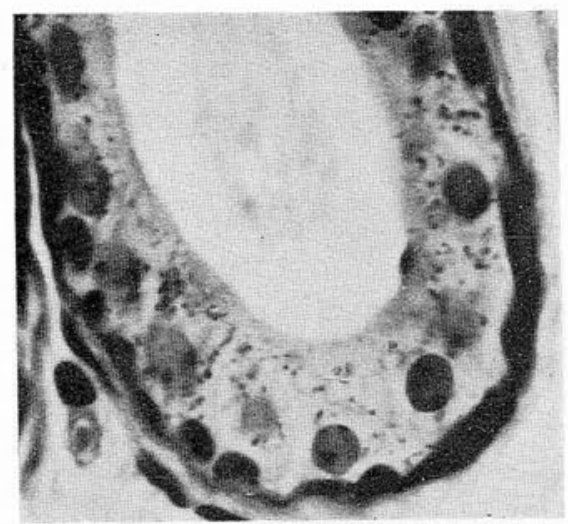

汹6. 腺新胞に於ける系柆体からの分泌顆柆。 形成. 耳道腺, 50才男. Zenker-Formal 固定, 鉄へマトキンリン (Heidenhain) 染色. $1100 \times$.

Abb. 6. Sekretgranulabildung aus Mitochondrien in Drüsenzellen. Ohrenschmalzdrüse, 50 jähr. Mann. ZENKER-Formol, Eisenhämatoxylin (HEIDENHAIN). 1100 $\times$.

が多い，かかる分泌顆粒の形成は核上 部即ち Golgi 野飞限局せず，核を囲む 細胞質領域で行われ，分泌顆䊀は核を 囲んで出現し, 細胞基底部にも認めら れる。一般飞外分泌腺細胞では分泌顆 粒は細胞先端部に集積することが多い が，尾曾越（1951）も見たよ5に耳道 脉ではやや趣を異にし，核を囲んで集 る傾问がある（図 $8,12,13$ ). 大田 (1950 a) は人の䀨毛腺細胞で同様な所 見を得たが，分泌顆粒の核内形成を認 めた．分泌顆粒を多く持つ細胞では短 桿状或は顆䊀状の系粒体が，細胞先端 部に少数に認められることが多い.

以上の如き分泌顆精形成は円柱形或 は立方形細胞で旺盛であるが, 低くて 扁平に近い細胞でも見られる. 上記の如き所見から見て高年者 に於ても耳道腺細胞の分泌顆梳 形成機能の減退はないよ 5 亿思 われる.

c）分泌顆粒，脂肪顆籹，色 絜顆粒及び分泌空胞.

耳道腺の腺細胞の細胞質には 脂肪顆籹，色素顆粒，分泌顆粒 及び分泌空胞等の存在が報告さ れている. 特に脂肪顆粒と色絜 顆精とについては多くの学者が これを認め, 耳道腺の脂肪分泌 と色素分泌が論ぜられた（尾曾 越 1951 参照)。最近 Montagna,

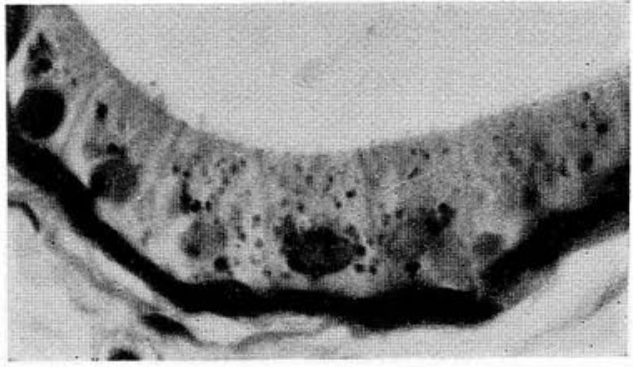

四 7. 腺細胞の核周囲飞於ける種々の大ささの分䎵 顆植の出現，腺紐胞の表面には刷子縁が見える。 H 道腺，50才男。Zenker-Formol 固定，鉄へマトキン リン染色. $1100 \times$.

Abb. 7. Vorkommen verschiedengroßer Sekretgranula in der Umgebung der Drüsenzellenkerne. Auf der Oberfläche der Drüsenzellen ist der Bürstensaum zu sehen. Ohrenschmalzdrüse, 50 jähr. Mann. ZENKER-Formol, Eisenhämat. $1100 \times$.

Noback とZak (1948) は人に於て, Montagna (1949) は猫に於て耳道腺について詳 細な組織化学的研究を行ったが, 特に人の耳道腺に於ける研究は重要である. 彼 等は人の耳道腺細胞に出現する脂肪顆籹と色素顆粒を組織化学的に研究したのみ でなく, Phosphatase と Lipase, 好塩基性物質 (RNA), グリコグン等をも観察した. 併し彼等は分泌顆精について記臷しないばかりでなく, 分泌顆粒, 脂肪顆粒, 色 素顆粒の相互関係について触れていない，彼等のの論文を姯むと之等の顆粒を別個 
のるのとして取扱っている よ5飞思われる. 尾曾越 (1951) は之等のの顆精が, Minamitani (1941b) が人の 腋㸗 アー汗腺で証明したよ うに, 全く同一の顆粒であ ることを証明した. 即ち鉄 へマトキンリンで強染する 分泌顆粒が成熟すると共に 脂肪と黄色一黄褐色の色素 を含むようになり，鉄へマ トキシリンで染色される部 分は少なくなって, 遂に空 胞化して分泌空胞となるが,

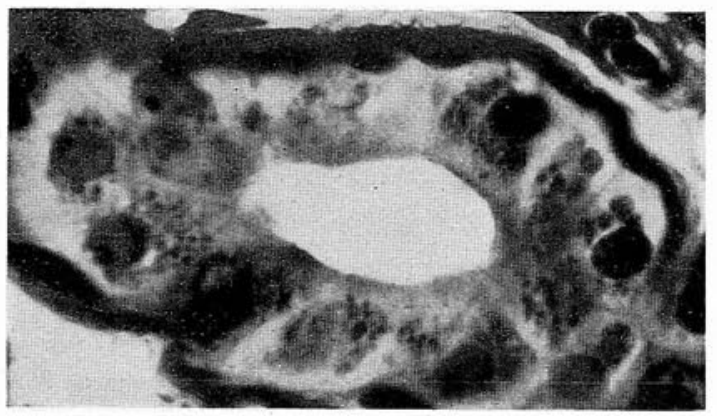

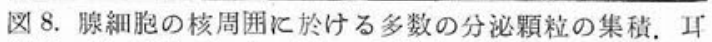
道腺, 50 才男. Zenker-Formol 固定, 鉄へマトキシリン 染色. $1100 \times$.

Abb. 8. Anhäufung zahlreicher Sekretgranula in der Umgebung der Kerne der Drüsenzellen. Ohrenschmalzdrüse, 50 jähr. Mann. ZENKER-Formol, Eisenhämat. $1100 \times$.

その中には易溶性の脂肪を含む分泌液が含まれる。尾曽越は耳道腺細胞では分泌 空胞を見た唯一人の学者であるが, Montagna, NobackとZak (1948) も谏結切片 で耳道腺細胞の脂肪顆粒を染色する場合に，核周囲にある小顆粒は Sudan black で染色されるが，大なる顆粒 (滴)は溶解されて染まらないと述べた。このことは 非常飞易溶性の脂肪性内容を持つ空胞の存在を示すよう飞思われる.

吾々は高年者の耳道腺細胞飞於て分泌顆粒, 色素顆粒, 脂肪顆粒及び分泌空胞 の存在を認め, 尾曾越 (1951) と同じ分泌像を確かめることが出来た.

Zenker-Formol 固定, 鉄へマトキシリン染色標本で観察すると上述の如く糸粒 体から形成された分泌顆粒は一般にエ-汗腺のものより粗大であるが, 色々の大き さを持ち核の周冊に集る(図 $8,12,13$ ). 一般に鉄へマトキンリンで好染するが, 中には染色性が弱いもの, 周辺部のみ㡏状, 半月状等に強染するが, 中心部の染

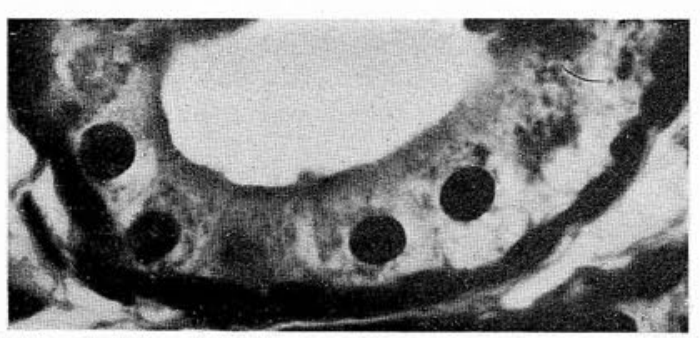

区 9. 腺紐胞の核周囲と基底部に的ける分泌空胞の出現. 耳道腺, 50 才男. Zenker-Formol 固定, 鉄へマトキシリ ン染色. $1100 \times$.

Abb. 9. Vorkommen Sekretvakuolen im parenukleären und basalen Abschnitt der Drüsenzellen. Ohrenschmalzdrüse, 50 jähr. Mann. ZENKER-Formol, Eisenhämat. $1100 \times$.
色が弱いものもある（輸状 顆粒). かかる分泌顆粒。を 多く持つ細胞の他に細胞の 基底部から核周囲部飞互っ て分泌顆䊀より大きい空胞 で充たされた細胞がある (図 9). 細胞先端部と空胞 の間には㷏状及び顆䊀状の 糸粒体の他に色々の大きさ の分泌頪粒があり, 糸粒体 から分泌顆粒の形成される 像があり, 中には中心部の 
染色性が低下した輪状の顆粒も見える. 輪状顆粒の中には空胞に近い大きさを持 ち周辺部のみ僅か、染色性を保ち正に空胞に転化しつつあることを思わしめるす のもある、以上の所見から考えると, 分泌顆粒は中心部から漸次染色性を失い遂 飞空胞となるよう飞思われる，かかる分泌顆粒の空胞化或は液化は細胞の核周囲 部から基底部で早く進行し, 漸次細胞先端部へ波及するものと思われる. 空胞化 の高度の細胞では核上部から先端部まで空胞で充満し, 先端部にある都皮層は㳿 次薄くなるのが見られる (図10). かかる細胞は飽満して円味を带び核は細胞の中

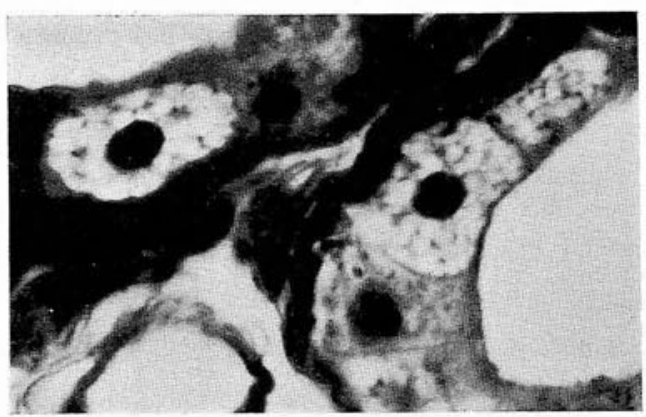

四 10, 分泌空胞で充たされた腺細胞，皮脂腺と似て いる. 分泌空胞の間には分泌顆柆が見える. 耳道腺, 50 才男. Zenker-Formol固定, 鉄へマトキシリン染色. $1100 \times$.

Abb. 10. Mit zahlreichen Sekretvakuolen ausgefüllte, abgerundete Drüsenzellen, welche den Talgdrüsenzellen ähnlich aussehen. Zwischen Sekretvakuolen sind Sekretgranula zu sehen. Ohrenschmalzdrüse, 50 jähr. Mann. ZENKER-Formol, Eisenhämat. $1100 \times$.
央近く空胞の中に浮ぶ如き観を 呈し, 核膜には屢々空胞による 压痕が熟められ, 尾曾越 (1951), Montagna 等: (1948) の言 $う$ 如く 皮脂腺細胞によく似た姿を持つ. 以上の如き分泌顆粒の出現, そ の空胞化の所見は他の外分泌腺 飞子屡々㷫められる分泌像と一 致し, 尾曾越の報告に照らして 見ると, 高年者飞於て子分泌像 飞変化はなく, 又との程度も決 して壮年者に劣ることがないと 思われる. 又かかる分泌像田 柱形乃至立方形の細胞飞限らず 扁平飞近い低い細胞飞る認めら れる(図11).

耳道腺の分泌顆精は尾曾越も述べているょうと色々の固定液 (例えば Formol, Formol-Alkohol) でよく保存されるので，その主成分は蛋白質であると思われるが， 分泌像も蛋白腺 (嶈液腺)のとれと一致する. 空胞は分泌液を容れる分泌空胞で ある.

次ぎに Zenker-Formol 固定, ヘマトキシリンーエオシン染色標本で分泌像を観察 すると分泌顆精と色素との関係がよく判る. 鉄へマトキシリン染色標本で分泌機 能の存在する部位即ち主として核を囲んで, 大きさ, 形及び数に於ても分泌顆粒と 一致する黄色乃至黄褐色の色素顆䊀が認められ, その一部のものはエオシンで染 るが，大多数のるのは染まらない，この所見から考えると分泌顆粒と色素顆粒は 同一のものであり, 分泌顆粒は色素を持つと断定される. この色素顆籹にも分泌 顆粒と全く同じ空胞化の過程が見られる. 即ち中央部の色調の弱い輪状顆粒及び 空胞の壁が黄色調を示するの，全く色を持たない空胞等である. 又空胞の間飞る 分泌顆粒と全く一致する色々な色秦顆䊀がある. これによって見ると色素は分泌 顆精の蛋白質と紿合してあり, それと全く同じ変化の過程をたどるるのであるこ 
とが判る. 分泌顆精が色素を担荷す ることを念頭に颃いて，鉄へマトキ ンリン染色標本を見ると, 鉄へマト キシリンで染まった分泌顆粒が黄乃 至褐色の色調を带びているととを看 取出来る場合がある.

更に Levi氏液固定, 鉄へマトキシ リン染色標本を見ると, Levi氏液に 含まれたオスミューム酸によって脂 肪が黒褐一褐色飞染まって保存され るので, 分泌顆粒と脂肪顆粒の関係 が観察される. この標本に於ても分 泌顆粒は鉄へマトキンリンで染色さ れて認められ (図 12), 中には中心部 の染色性が減弱し, 周辺部の及強染 する輸状顆粒があるが(図13), それ

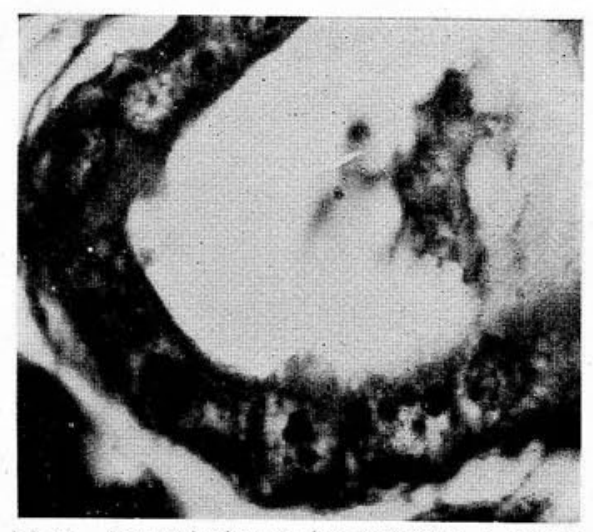

図 11. 低い腺細胞の粗大な分泌顆粒と分泌空 胞. 耳道腺, 83 才女. Levi氏液固定, 欲へマト キシリン染色. $1100 \times$.

Abb. 11. Grobe Sekretgranula und Sekretvakuolen in niedrigen Drüsenzellen. Ohrenschmalzdrüse, 83 jähr. Frau. LEVIsches Gemisch, Eisenhämat. $1100 \times$.

等の中心部はオスミューム酸 で黒褐乃至褐色飞呈色し, 脂 肪を持つことが判る. 即ち分 泌顆粒は脂肪を持つ. 中には 鉄へマトキンリンで染まらな いで完全な脂肪顆粒として認 められるるのるある. 即ち分 泌顆精が染色性を失うことに より，脂肪を含むことが明ら かとなる. 空胞の中には全く オスミューム酸で染まらない ものるあるが, 中にはオスミ ニーム酸で淡く黒褐一褐色に 染まる内容を持つるのが認め られる. 以上の所見から考察 すると, 分泌顆籹は脂肪を担
図 12. 多数の分泌顆粒を持つ高门柱形腺細胞と空胞化 し腫大した筋上皮細胞 ( $\uparrow$ ). 耳道腺, 89 才男. Levi 氏 液固定, 鉄へマトキンリン染色. $1100 \times$.

Abb. 12. Zahlreiche Sekretgranula enthaltende hochzylindrische Drüsenzellen und vakuolisiert angeschwollene Myoepithelzellen ( $\uparrow$ ). Ohrenschmalzdrüse, 89 jähr. Mann. LEVIsches Gemisch, Eisenhämat. $1100 \times$.

荷し, 分泌顆籹の空胞化飞よって坐ずる分泌空胞も非常に易溶性で稀薄な脂肪を 含む内容を持つ. 即ち分泌空胞は脂肪を持ち, それねよって充たされた肥満した 細胞は化学的に見ても皮脂腺細胞と極めて類似することが判る. 尾嘼越 (1951) す述へたた如く, 耳道腺細胞の分泌顆籹の脂肪化は非常に強く, 従ってその脂肪分 泌は形態学的にも十分証明される. 而して脂肪化は高年者に於ても決して減弱し 


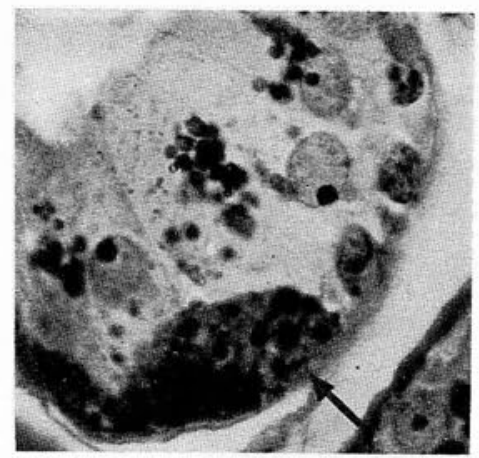

四 13. 粗大分泌顆柆を持つ高円柱形 腺細胞と多数のリポフスチン顆粒で充 たされ肥大した解上皮細胞 (个). 耳道 腺, 89才男. Levi氏液固定, 鉄へマト キンリン染色. $1100 \times$.

Abb. 13. Grobe Sekretgranula führende, hochzylindrische Drüsenzellen und durch viele Lipofuszingranula stark ausgefüllt vergrößerte Myoepithelzelle ( $\uparrow$ ). Ohrenschmalzdrüse, 89 jähr. Mann. LEVIsches Gemisch, Eisenhämat. $1100 \times$.

起を作って腺腔へ突出する. 恰も钤度層が笑起を形成する 如き観がある (図 14, 15). 突 起の中には稀れ飞分泌顆粒や 空胞が見られるととるある. 突起の大きさ及び長さは種々 であり, 腺腔面の全域から膨 出することるあり, その1部 から小笑起が出されることも ある。原形質突起は根本或は 途中で縊れて離断され腺堙へ 滴状物として脱落する(図15). アー分泌像を示す腺細胞は総 て分泌顆粒や空胞を持つ.

耳道腺細胞のエックリン分泌について尾曾越（1951）は腺細胞が分泌空胞で充 たされ，凯皮層が消失した細胞ではエー分泌が考光られると述べ，吾々も上述した ような分泌空胞で充満し, 肥満して度脂腺細胞飞近似する形態を示す細胞を高年 者に於て認めたが，微皮層が殆んど消失し，分泌空胞が薄い原形質膜で腺腔から 隔てられる如き状態に於てはエックリン分泌を考至ざるを得ない（図10).かか
ているとは思われない，以上の観察によっ て分泌顆䊉と脂肪顆粒も亦同一のものであ るととが証明された，従って耳道腺細胞の 分泌顆料は色素及び脂肪を担荷することが 明らかとなった。これは尾曾越の壮年者に 於ける成績と一致する.

d） 耳道腺細胞のアポクリン分泌とエッ クリン分泌.

高年者の耳道腺飞も全例飞於いてアポク リン分泌像が垫められ，89才例飞於ても旺 盛である. 従ってア-分泌は高年者に於て も減衰するとは思われない，

尾曾越 (1951) も还へているようにア-分 泌が見られるのは円柱形及び立方形の腺細 胞で, 特飞遊離表面飞厚い凯皮層を持つ細 胞のみに見られる。低い細胞には殆んど見 られない，アー分泌に際して暗調均質性の 凯度層が乳頭状, 舌状等の暗調な原形質突

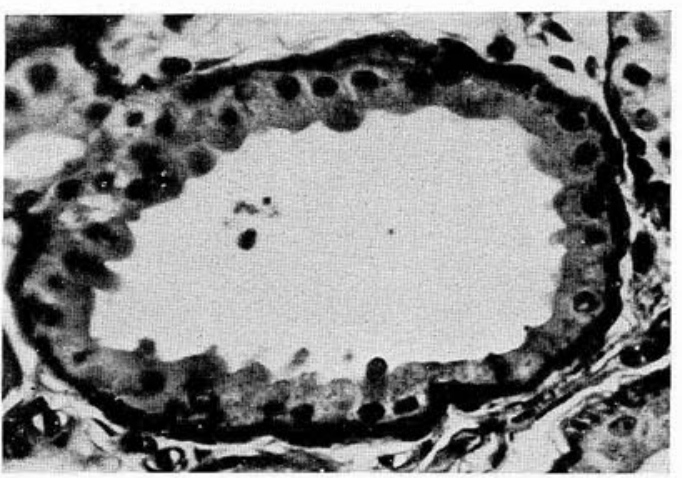

区14. 腺細胞のアボクリン分泌. 耳道腺, 50 才男. Zenker-Formol 固定, 鉄へマトキシリン染色. $480 \times$.

Abb. 14. Apokrine Sekretion der Drüsenzellen. Ohrenschmalzdrüse, 50 jähr. Mann. ZENKER-Formol, Eisenhämat. $480 \times$. 
る細胞には実際アー分泌像は全く認め られなかった。 かかる細胞に於て殸皮 層が全く消失するのは, 細胞内に増加 する分泌空胞によって凯皮層が侵蝕さ れることも考えられるが, 又上述の如 くアー分泌によって就皮層が突起を形 成して腺腔へ脱落することによって消 耗されるためとる考えられる. 從って 高年者の耳道腺飞於ても尾曾越(1951) の説の如くア-分泌はエ-分泌に先行す るという仮定が成立する.

腺細胞の腺腔への脱落は極めて稀れ そ認められたのみである. 脱落腺細胞 は円形化し, 細胞質は空胞で充たされ, 核は不規則な形を示す，高年者に於て あ極めて稀れに見られるのみであって ホロクリン分泌を考える必要はないと 思5.

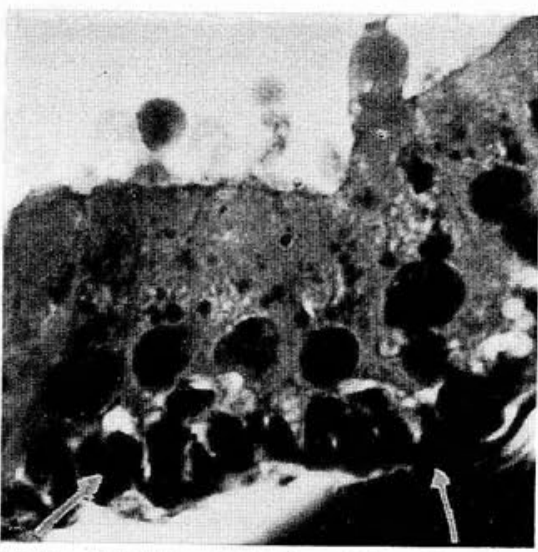

区 15. 腺細胞のアポクリン分泌。核上部に は Golgi 装蒀の陰像 (明細管) が見える。空 胞化し腫大した筋上皮細胞 ( $\uparrow)$. 耳道腺, 89 才男. Levi 氏液固定, 鉄へマトキンリン染 色. $1100 \times$.

Abb. 15. Apokrine Sekretion der Drüsenzellen, negative Bilder des Golgiapparates (helle Kanälchen) im Supranuklearabschnitt der Drüsenzellen und vakuolisiert angeschwollene Myoepithelzellen ( $\uparrow$ ). Ohrenschmalzdrüse, 89 jähr. Mann. LEVIsches Gemisch, Eisenhämat. $1100 \times$.

\section{C. 高年者耳道腺の腺管壁に認められる異常.}

高年者の耳道腺には上述の如く老人性萎縮は殆んどなく腺細胞の分泌機能にも 形態学的に見て殆んど変化はない. 併し腺細胞には次ぎに述へる如き変化が認め られ，特に筋上皮細胞には可なり高度の変化が見られた。

a) 腺細胞の変化.

伊東と岩重 (1953) は高年者の腋㸗ア-汗腺細胞に現われる変化として細胞質の 空胞化, 混濁唖脹, 軽度の脂肪化 (脂肪滴の出現), 粗大顆粒による細胞の充盈及 び円形化等を挙げた，高年者の耳道腺に於ては之等の変化は殆んど認められない が，63才例に於てのみ次の如き変化が見られた。第 1 に少数ではあるが混濁腫脹 と思われる変化がある. 即ち細胞は腫大円形化し, 細胞質は混濁し, 糸粒体, 分 泌顆粒等は全く証明されず，殸皮層も消失している、核は細胞の中央部にあり， 不規則形をとるるのがある(図16). 第 2 とは細胞質の空胞化である. これは可な り多くの腺細胞に現われ, 細胞質は不規則形, 不等大の空胞で充たされ全く明調 で不規則な泡沫㥞に見え, 系粒体, 分泌顆粒, 款皮層は証明されず, 核は不規則 形となる(図17). 上述の腺腔に脱落した腺細胞と近似する. 上記の如く耳道腺細 胞には分泌空胞で充たされた分泌時期に在るものがあるが，その場合には空胞は 規則正しい形を持ち，空胞間に分泌顆粒，糸粒体等があり，空胞は霓々オスミニ 


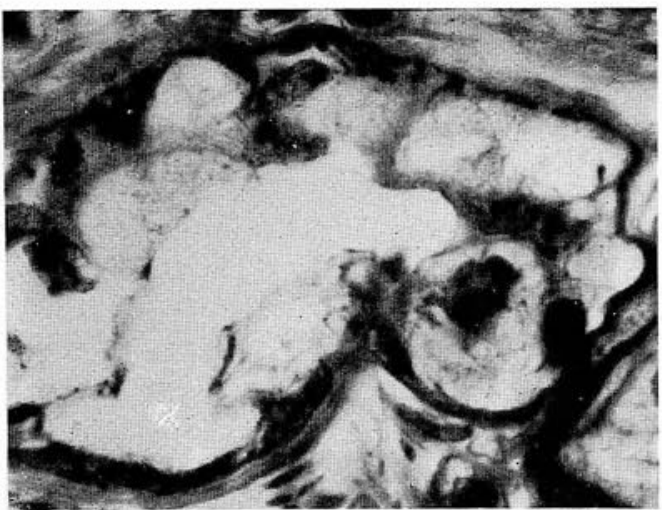

図 16. 瑔紐胞の混罚腫脹。耳道腺，63才男。 Levi氏液 固定，鉄へマトキシリン染色. $1100 \times$.

Abb. 16. Trübe Anschwellung der Drüsenzellen. Ohrenschmalzdrüse, 63 jähr. Mann. LEVIsches Gemisch, Eisenhämat. $1100 \times$.
ーム酸に染まる稀薄な脂肪性 内容を持つのが見られるが， かかる空胞化の場合には全く 明調である。耳道腺細胞では 単なる脂肪滴の出現はないよ うに思われる。 以上の如き変 化を老人性変化と見做すのは 早計である。それはかかる変 化が63才例飞のみ見られ，而 もこの例は脳軟化症の患者か ら得た材料であるためである. 更にこの例には次の如き興 味ある変化が見出された（図 18）。困18 亿見るようと腺管 を囲む間質結合組織は空胞化

して泡沫様の細胞 質を持つ円形化し た多数の大きい細 胞で充満する。こ の細胞の核は楕円 形或は不規則形で 比䡠的大きい核小 体を持ち, 細胞の 1 側飞偏在するこ とが多い、かかる 細胞は上にのべた 空胞化した腺細胞 と非常飞似ていて 結合組織性のもの とは考えられない.

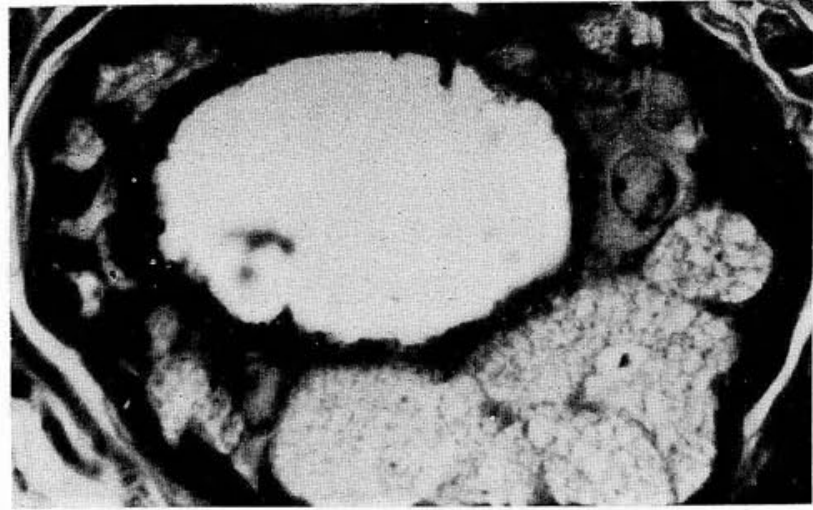

図 17. 空胞化して腫大した腺細胞。耳道腺, 63 才男. Levi 氏液固 定，鉄へマトキシリン染色. $1100 \times$.

Abb. 17. Vakuolisiert angeschwollene Drüsenzellen. Ohrenschmalzdrüse, 63 jähr. Mann. LEVIsches Gemisch, Eisenhämat. $1100 \times$. 恐らく腺腔を失った腺管壁の腺細胞が，結合組織の中へ拡がったるのであろう. この腺の腺管の 1 部に於ては腺細胞は略々正常でアー分泌像を示すが, 他の部分に 於ては腺細胞の空胞化, 混濁腫脹, 筋上皮細胞の高度の腫大空胞化 (図 .18) 等が 見られた。

b) 筋上皮細胞 (平滑筋細胞) の変化.

狩野 (1951) と岩重 (1952) は高年者のエ-汗腺に於て筋上皮細胞の萎縮, 脂肪化, リポフスチン顆粒の出現, 腫大, 空胞化等の変化を認め, その收縮機能の低下を 


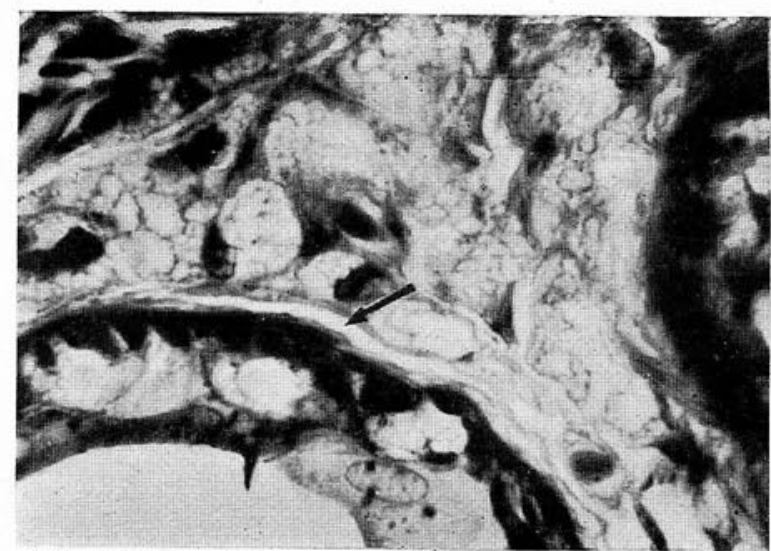

困 18. 間質結合組織内へ拡がつた空胞化し円形化した腺細胞と 空胞化䏦大した飭上皮細胞 ( $\uparrow$ ). 耳道腺，63才男。 Levi氏液固 定，鉄へマトキシリン染色. $1100 \times$.

Abb. 18. Ausbreitung der vakuolisierten und abgerundeten Drüsenzellen in das interstitielle Bindegewebe $\mathrm{zwischen}$ den Drüsentubuli und vakuolisiert angeschwollene Myoepithelzellen $(\uparrow)$. Ohrenschmalzdrüse, 63 jähr. Mann. LEVIsches Gemisch, Eisenhämat. $1100 \times$.

想定した。伊東と岩重 （1953） ๖ 高年者の腋 㸗 ア-汗腺に於て筋上 皮細胞の同栐な変化を 認めた. 之等の変化は 恐らく汗腺に現われる 老人性変化と見做して よいようと思われる。 吾々は上述の如く高年 者の耳道腺には未だ殆 えど老人性変化と言う べきものを認めていな い. 併し筋上皮細胞に は全例に於て上に挙げ た学者が認めたものと 一致する, 老人性変化 と思われる可なり高度 の変化を認めた，筋上

皮細胞の萎縮は確認するととは出来な かったが，腫大と空胞化は多く認めら れ，両偖は相伴って現われることもあ る（図12,15,18）。筋上皮細胞は腫大 膨化し，大なる明るい丘形細胞として 腺細胞の基底部飞突出する. 又リポフ スチン顆䊀も同㥞に多く認められる. 黄一黄褐色の顆粒で, オスミューム酸 によって黑化し，鉄へマトキシリンで 染まる (図19) 点は分泌顆䊉と似てい る. 核の近囲に現われ，多い場合には 筋細胞は顆粒によって大きく飽満して 腺細胞の基底部へ㚙出する(図13)。脂 肪滴の出現は少ない.

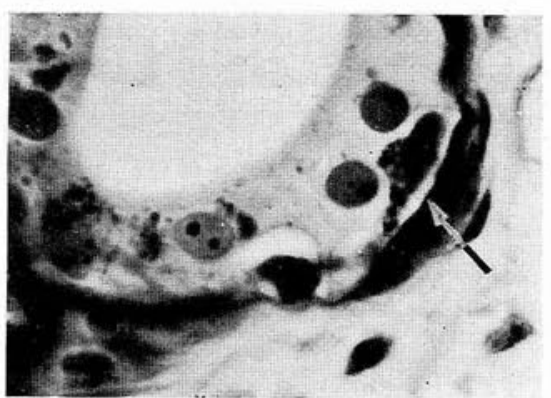

図 19. 腫大した筋上皮細胞とりポフスチン 顆粓を持つ筋上皮細胞 ( $\uparrow)$. 耳道腺, 50 才 男. Zenker-Formol 固定, 鉄へマトキンリ ン染色. $1100 \times$.

Abb. 19. Angeschwollene und Lipofuszingranula führende Myoepithelzellen $(\uparrow)$. Ohrenschmalzdrüse, 50 jähr. Mann. ZENKER-Formol, Eisenhämat. $1100 \times$.

上記の変化は恐らく筋上皮細胞の機能の低下を伴うすのと思われる.

\section{D. 耳道腺に於ける PAS 陽性物質.}

アー汗腺の分泌顆粒が唾液消化而性, PAS 晹性なることは Montagna, Chase と Hamilton (1951, 陰丘ア-汗腺), Montagna, Chase とLobitz (1953, 腋㸗ア-汗腺) 
等によって報告され，伊東と岩重 (1.953) は腋简アー汗腺飞於てPAS 晹性の颗精は 脂肪と色素とを持ら，腺細胞の先端部に集をるMinamitani (194.1 b) の所謂成熟分 泌顆粒であり，鉄反応を示吉顆粒。(岩重 1951 参照)と一致し，未熟分泌顆粓はPAS 除性であると論じた。吾々は本研究に於て耳道腺細胞の核の近团に集る，脂肪と 色素を含む分泌顆粓はPAS 陽性であるのを認めた．陽性反忍がグリコゲンによ るのでないことは睡液消化試騟によって明らかである. Montagna, Noback と Zak （1948）は人の耳追腺細胞の色素顆䊀がPAS 陽性であると述べたが，これは吾々 の分泌顆粒を指していることは明瞭である。吾々は分泌顆䊀が反応陽性であると 言うのが正しいと思う。.Lillie（1950）によれば一定の漿液腺の分泌顆精はPAS 陽性であり，又人のエー汗腺の表層細胞の分泌顆料もPAS 陽性であって，之等の 腺の分泌顆䊀はいら゙れも色素を持っていない.

次ぎに上にのべたように耳道腺細胞の殼皮層の袁面にある刷子縁るPAS 陽性 であって，これを形成する小桿（原形質突起, microvilli）が陽性飞反応し，全体と してPAS 反応で紅紫色飞染まる薄い縁として殻皮曆の表面を被う(伊東, 高橋と 北川 1956 参照).

アー汗腺の腺腔飞渚溜するコロイド状の内容 (分泌物) が Bauer 氏反心 (クロー ム酸-Schiff 反応) 飞対して陽怯に反态することが, Bunting, Wislocki と Dempsey (1948)，大田 (1950b) によって報告されたが，その後唾液消化耐性，PAS 陽性な るととが Montagna, Chase とLobitz (1953)，伊東と岩重 (1953) によって証明され， 又胎生期の腋窞ア-汗腺 (土屋 1954) 及び耳道腺（成田 1954）飞於ても証明された。 吾从も本研究に於て 63 才と 83 才の 2 例に於て腺管が搪大しコロイド状或は雲架 状の内容を充たした腺を多く認めたが，その内容はPAS 法飞対して非常飞強い陽 监反応を示し，唾液消化によって反応は減弱しない，Montagna，NobackとZak (1948) の報告と一致する。

筋上皮細胞飞屢々出現するリポフステン顆粒子分泌顆粒と同様に PAS 陽性で める。

次ぎに腺細胞のグリコゲンであるが，一般にア-汗腺細胞はグリコゲンを持た ないと洘えられている（伊東と大田 1949）. Bunting, Wislockiと Dempsey (1948)， Montagna, Chase とLobitz (1953) 等もこれを認めたが, 大田 (1950 b)は腋臭のな い日本人の腋品アー汗腺には少量のグリコダンを持つるのがあると述べ, 伊東と 大田 (1949) 子服简の非其型的アー汗腺 (Minamitani 1941a 参照)の腺細胞はグリコ ダンを持つと報告した。 又陰早アー汗腺の腺細胞の中にはグリコゲンの証明され るぬのがあると報告されている(Montagna, Chase と Hamilton 1951). Montagna, Noback とZak (1948) は人の耳道腺細胞に於てグリコダン顆粒が分泌顆粒（色素 顆料）の間に散在して認められると述べたが, 吾々はこれを確かめることが出来 なかった．高年者の耳道腺細胞はグリコダンを持たないように思われる，成田 (1954) 飞よれば胎生期の耳道腺の腺細胞は胎生全期に互って少量のグリコダン 
を持ち，排泄管上皮の外層細胞は多量飞持つという。排泄管上皮及び筋上皮細胞 にもグリコゲンは証明されなかった。

\section{III. 総 括.}

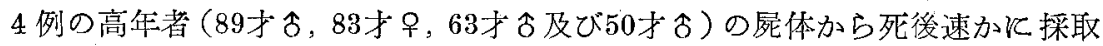
した外耳道軟骨部皮膚の耳道腺を細胞学的飞詳細飞観察し，高年者に於ける耳道 腺の変化を追及した。

1. 高年者の耳道腺には老人性萎縮の幑は殆んど認められない. 即ち腺体（糸 毬)の大きさ，腺管の太さ，腺細胞の大きさ等に萎緶は殆んどない，腺細胞は円柱 形, 立方形, 扁平等であるが，一般に腺腔の搪大した部分では腺細胞は低く，狭い 部分では高い，63才と83才の 2 例では腺腔が著しく搪大し，腺腔がコロイド状或 は雲絮状のPAS 強陽性, 唾液消化耐性の内容で充たされた腺が認められた。

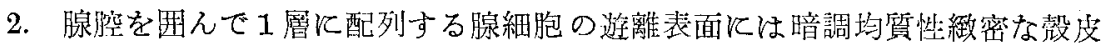
層があり，その表面にはPAS 陽性の刷子縁がある。核は一般に大なる核小体を持 ち，全例飞於て脂肪細胞の有孔核を思わしめる空胞を持つるのがある。併しとれ が老人性変化であるか否かは明らかでない。

3. 高年者の耳道腺細胞は主として糸状及び桿状の糸粓体を持ち，その数は89 才例に於ても減少していない. 糸粒体から分泌顆精の形成される像が見られるが， 高年者飞於ても分泌顆粒形成機能の低下を思わしめる所見はない.

4. 耳道腺細胞の粗大な分泌顆粒はPAS 陽性で, 高年者飞於ても黄色の色素々 脂肪を担荷し，その空胞化によって生ずる分泌空胞は極めて易溶性の脂肪を含も 分泌液を容れる，高年者飞於ても分泌空胞で充満し，飽満円形化して皮脂腺細胞

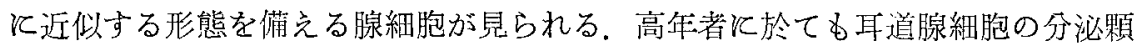
粒の色素含有及び脂游化は減弱せず，彷って脂肪及び色素分泌は減弱しないよう 炇思わ礼る。

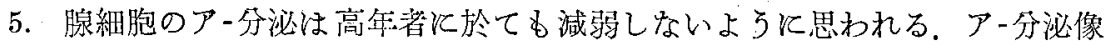
を示すのは厚い殼皮曆を持つ円柱形及び立方形の腺細胞であって，凯皮層が原形 質突起を形成し，腺腔へ絞断脱落する，笑起の中には稀れに空胞や分泌顆粶が含 まれることもある，アー分泌によって殸皮層は薄くなる，腺細胞には土一分泌も考 元られる。工ー分泌を行うのほ分泌空胞によって充たされた皮脂腺細胞を思わし める細胞であって，款皮層はア一分泌によって消耗され，分泌空胞によって侵蝕さ れて消失する，徒ってアー分泌はエー分泌先行すると想像される，ホロクリン分 泌を思わしめる所晃は殆んどない。

6. 63才脳軟化症屍の耳道腚細胞に注濁腫脹，空胞化等の変化が見られた他， 空胞化した腺細胞が間質組織へ搪散し，腺管の間を充たす像が認められた。等 の変化は63才例のみ浔められ老人性:変化とは考克られない.

7. 全例飞於て符上皮細胞の腫大, 空腔化, リポフスチン顆粒の出現, 脂肪化等 
が可なりの類度に於て認められた。これが本研究で見られた唯一の老人性変化と 思われる所見であった，かくの如き変化は当然筋上皮細胞の機能低下を想像せし める.

8. 排泄管は内層及び外層の 2 層の上皮細胞で团亲れ，短かくて系趢形成に与 らない，毛包上部へ開口寸るが，50才例飞於て管腔の拡大が見られた。

9. 腺細胞，排泄管上皮細胞及び筋上皮細胞には共にグリコダンは証明されな かった.

\section{IV. 結一語.}

50-89才の4例の高年者の耳邀腺を細胞学的に観察した絬果, 符上皮細胞に認 められた変化以外飞老人性変化と思われる変化は見られなかった。腺には萎維は なく、腺細胞の機能低下を示す如き形態学的所見は得られなかった。これによっ て見ると耳道腺々胎生期に於て最も早く機能を開始し，高年に到っても容易に機 能の衰退することのない腺であるということが出来る。

\section{Autoreferat.}

Bei 4 Fällen von Pars cartilaginea des äußeren Gehörgangs aus 4 Greisen (5089 jähr.) wurden die Gll. ceruminosae cytologisch eingehend studiert, um die senilen Veränderungen in diesen Drüsen zu erforschen.

1. In keinem Falle wurden Anzeichen der senilen Atrophie in den Bavelementen der G11. ceruminosae gefunden. Die Drüsenzellen waren cylindrisch, kubisch und abgeflacht gestaltet. In dem Drüsentubulus mit einem weiten Drüsenlumen waren sie gewöhnlich niedrig und in dem mit einem engen hoch. Die äußeren Gehörgänge aus 63 und 83 jährigen Greisen zeichneten sich durch das Vorkommen von vielen Ohrenschmalzdrüsen mit außerordentlich stark erweiterten Drüsenlichtungen aus, die mit einem PAS-positiven kolloidartigen oder wolkenartigen Sekretmasse ausgefüllt waren.

2. Die dem Drüsenlumen zugerückten Zonen der regelmäßig einschichitg angeordneten Drüsenzellen stellen gewöhnlich eine homogene dunkle Plasmaschicht, Krustenschicht, dar, deren freie Oberflächen mit einem dünnen PAS-positiven Bürstensaum versehen sind. Die Kerné der Drüsenzellen haben verhältnismäßig große Nucleolen und enthalten nicht seltem verschiedengroße Vakuolen, welche den Kernen der Drüsenzellen das Aussehen der Lochkerne der Fettzellen verleihen. Die Frage, ob diese Kernvakuolen der Drüsenzellen der senilen Veränderung zuzurechnen sein soll, wurde in dieser Untersuchung nicht gelöst.

3. Die Mitochondrien der Drüsenzellen waren faden-, stäbchen- und körnchenförmig geformt, ihre Zahl war sogar beim 89 jährigen Falle nicht reduziert. Die Bilder der Sekretgranulabildung aus Mitochondrien wurden bei den Greisen ebenso häufig wie bei jüngeren Individuen angetroffen, was davon sprach, da $\beta$ in den Ohrenschmalzdrüsen der Greise die Tätigkeit der Sekretgranulabildung nicht herabgesetzt war.

4. Die im allgemeinen groben Sekretgranula der Drüsenzellen waren in den 
Ohrenschmalzdrüsen der Greise ebenfalls PAS-positiv und mit gelblichem Pigment und Fett beladen und wandelten sich durch Verflüßigung in größere Sekretvakuolen um, die eine sehr leicht lösliches Fett enthaltende Sekretflüßigkeit führen. Die mit solchen fetthaltigen Sekretvakuolen hochgradig gefüllten, abgerundeten, den Talgdrüsenzellen ähnlich erscheinenden Drüsenzellen kamen bei den Greisen so häufig wie bei jüngeren Individuen vor. Sogar die Pigmentierung und Verfettung der Sekretgranula waren bei den Greisen nicht abschwächt, woraus hervorging, daß die Pigment- und Fettabsonderung der Ohrenschmalzdrüsen bei den höheren Alteren nicht herabgesetzt waren.

5. Die apokrine Sekretion der Drüsenzellen schien bei den Greisen nicht so weit herabzusteigen. Die Drüsenzellen, die die Bilder der apokrinen Sekretion zeigten, waren eylindrisch oder kubisch geformt, sie besaßen in der Regel eine verhältnismäßig dicke Krüstenschicht, welche bei der apokrinen Sekretion den ins Drüsenlumen hineinragenden Protoplasmafortsatz (Sekretfortsatz) bildete und schließlich als Sekrettröpfchen in das Lumen abgeschnürt wurde. Daher verdünnte sich die Krustenschicht der Drüsenzellen durch die apokrine Sekretion nach und nach. Außerdem wurde das Vorkommen der ekkrinen Sekretion bei solehen Drüsenzellen der Ohrenschmalzdrüsen angenommen, welche durch viele Sekretvakuolen so stark wie bei Talgdrüsenzellen ausgefüllt worden sind und ihre Krustenschicht auf die oben erwähnte Weise verloren haben. Die apokrine Sekretion scheint daher der ekkrinen voranzugehen. Das Vorkommen der holokrinen Sekretion wurde bei Ohrenschmalzdrüsen der Greise nicht festgestellt.

6. In den Ohrenschmalzdrüsen aus dem 63 jahrigen, an Hirnerweichung gestorbenen Greise wurden trübe Anschwellung und Vakuolisierung der Drüsenzellen häufig bemerkt. Außerdem wurde die Ausbreitung der abgerundeten, vakuolisierten Drüsenzellen ins interstitielle Bindegewebe zwischen den Drüsentubuli gesehen. Diese Veränderungen wurden aber nur in dem oben genannten Fall gefunden, so da 3 man sie nicht als senile Veränderungen betrachten konnte.

7. Bei jedem Falle wurde solche Veränderungen wie Anschwellung, Vakuolisierung, Vorkommen der Lipofuszingranula sowie der Fetttropfen (Verfettung) an den Myoepithelzellen (glatten Muskelfasern) häufig beobachtet. Diese Veräaderungen der Myoepithelien stellten wahrscheinlich die einzige Altersveränderung der Ohrenschmalzdrüsen dar. Diese Veränderungen deuteten möglicherweise auf die Herabsetzung der Tätigkeit der Myoepithelien hin.

8. Der Ausführungsgang der Ohrenschmalzdrüse hatte ein zweischitges Epithel in gleicher Weise wie bei anderen Schweißdrüsen. Er war gewöhnlich kurz und beteiligte sich nicht an der Knäuelbildung des Drüsentubulus, er mündete öfters an dem oberen Teil des Haarbalgs aus. Bei den Ohrenschmalzdrüsen aus dem $\mathbf{5 0}$ jährigen Mann wurde die Frweiterung der Ganglichtung nicht selten beobachtet.

9. Glykogen wurde in den Drüsenzellen, in den Fpithelien des Ausführungsgangs und in den Myoepithelien nicht nachgewiesen.

10. Auf Grund der obigen Ergebnisse kamen wir zu dem Schluss, daß an den Ohrenschmalzdrüsen der Greise außer den Veränderungen der Myoepithelien fast keine senilen Veränderungen festgestellt werden und weder die Atrophie der Bauelemente der Drüsen noch die Befunde, die von der Herabsetzung der Sekretionstätig- 
keit der Drüsenzellen sprechen, beobachtet werden. Es kann daher angenommen werden, daß die Sekretionstätigkeit der Ohrenschmalzdrüsen in der Fetalzeit am frühesten beginnt und in den Greisenaltern fast unabschwächt fortwährt.

\section{文献.}

Alzheimer, A.: Über die Ohrenschmalzdrüsen. Verh. Würzburger physik.-med. Gesell. N. F. 22 (1888). S. $221-240$. - Bunting, H., G. B. Wislocki and E. W. Dempsey : Chemical histology of human eccrine and apocrine sweat glands. Anat. Rec. 100 (1948). P. 61-77. - Eckert-Möbius, A. : Äußerer Gehörgang. Handbuch der Hals-, Nasen-, Ohrenheilkunde von Denker u. Kahler. Bd. 6. Tl. 1. S. 211. 1926. -- Herzenberg, H.: Neue Beiträge zur Lehre von den apokrinen Schweißdrüsen. Virchows Arch. 266 (1927). S. 422455，一広田雍夫：腋臭の統計的及䒠験的研究。成医誌５8(1939)。頁530-567. 一 Ito, T.： Über den Golgiapparat der ekkrinen Schweißdrüsenzellen der menschlichen Haut. Fol. anat. ja p. 22(1943). S. 273-280. 一伊東倰夫：汗腺の組織学と細胞学。医学の進歩. 6輯. 頁106221. 1949. 一伊東倰夫, 大田隆子：汗腺のグリコダンに関する知見補遺. 生体の科学. 1 (1949). 頁 146-148. 一伊東倰夫, 円乘 幸：汗腺排淮管の細胞学的研究. 腺管と排泟管之 の移行部の研究。生体の科兴. 1 (1949). 頁 69--73. 一伊東倰夫, 岩重 毅：健康な高年者の

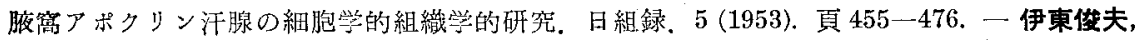
成田安弘, 大屋正夫, 永川佳彦：人胎皃皮下脂肪組織の組織発生学的及び細胞学的哳究。日 組録。11 (1956), 頁 131-164. 一伊東倰夫, 高楿照明, 北川高久：人の汗腺の上皮細胞飞於 ける刷子縁の出現について。日組録。11(1956)。頁 317-328.一岩重 教：日本人腋窝アポ

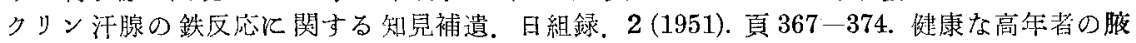
窝エッタリン汗腺の細胞学的組織学的研究。 日組録。 4 (1952). 頁 75-90. 一官冒夫：邦人

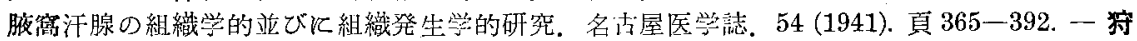
野好一郎：高年者の汗腺の細胞学的組織学的研究, 病豦友層爪於けるエ-汗腺の観察. 目組録. 3 (1951). 頁 91一195. 一小山正道：皮㳙腺飞於ける脂肪飞就いて。東京医新誌. 2451 (1925). 頁 2722-2723. - Lillie, R. D.: Further exploration of the HIO4-Schiff reaction with remarks on its significance. Anat. Rec. 108 (1950). P. 239-253. - Minamitani, K.: Zytologische und histologische Untersuchungen der Schweißdrüsen in mensehlicher Achselhaut. Über das Vorkommen der besonderen Formen der apokrinen und ekkrinen Schweißdrüsen usw. Fol. anat. jap. 20 (1941 a). S. 563-590. - Zur Zytologie der apokrinen Scinweißdrüsen usw. Fol. anat. jap. 21 (1941 b). S. 61-94. - Montagna, W.: The glands in the external auditory meatus of the cat. J. Morph. 85 (1949). P. 423-441. - Montagna, W., C. R. Noback and F.G.Zak: Pigment, Lipids, and other substances in the glands of the external auditory meatus of man. Amer. J. Anat. 83 (1948). P. $409-435$. Montagna, W., H.B.Chase a J.B. Hamilton: The distribution of glycogen and lipids in human skin. J. Invest. Derm. 17 (1951). P. 147-157. - Montagna, W., H. B. Chase a. W. C. Lobitz: Histology and cytochemistry of human skin. V. Axillary apocrine sweat glands. Amer. J. Anat. 92 (1953). P. 451-470. 一永川货店：人胎児腋窝アポクリン汗脉 ○組織発生学的細胞学的研究。日組録。12 (1957). 頁 27-70. 一長島次男: 本邦人の耵㙏腺 及び耵贾、特飞腋臭症との関係飞就て。皮尿誌. 36 (1934). 頁690-704. 一成田安弘：人胎 児ていねい腺の細胞学的研究。日組録。 7 (1954). 頁 19-38. - Nicolas, J., C. Regaud et M. Favre: Sur la fine structure des glandes sudoripares de l'homme, etc, O. R. Ass. Anat. 14. Reun. Bibliogr. anat. 1912. Suppl. P. 201. (Minamitani 1941 b. 引用),一大田隆子：睷 毛腺 Glandula sudorifera ciliaris (モル氏腺) の細胞学的研究．日新医学．37(1950 a). 頁 174 -179, 一正常 (非腋㚖者) 腋窝皮菺の所請アポクリン汗腺の細胞学的, 組織学的研究, 日組 録. $1(1950$ b). 頁 285-308. 一尾兽越 秀: てい权い脉（耳道腺）の細胞学的研究, 日組録. 
2 (1951). 頁 153-173. - Stöhr, Ph. (u. v. Müllendorff u. Goerttler): Lehrbuch der

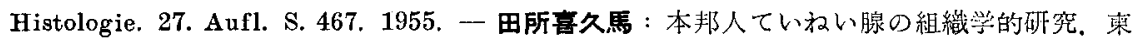
京医会誌. 23 (1909). 頁 890. 一土屋和子：人胎児エックリン汗腺の研究. 特飞その組織及 び細胞発生に就て。日組録。6 (1954). 頁 403-432. 